\title{
Traditional uses of African rosewood (Pterocarpus erinaceus Poir. Fabaceae) through the sociolinguistic groups and the pathways of conservation and sustainable management in Benin
}

\author{
Christine Ouinsavi $^{1}$, Bienvenue Nawan Kuiga Sourou ${ }^{1^{\star}}$, Adigla Appolinaire Wédjangnon ${ }^{1}$, \\ Towanou Houêtchégnon ${ }^{1}$, Yanik Akin ${ }^{1,2}$ and Justin Dossou ${ }^{1}$ \\ ${ }^{1}$ Laboratoire d'Etudes et de Recherches Forestières (LERF), University of Parakou, 03BP 123 Parakou, Benin. \\ ${ }^{2}$ Laboratoire de Biostatistiques et d'Estimations Forestières, University of Abomey-Calavi, 04BP 1525 Cotonou, Benin.
}

Received 30 July, 2021; Accepted 3 November, 2021

\begin{abstract}
Pterocarpus erinaceus Poir, a spontaneous species from Guinean savannahs of West Africa, functions as socio-economic and cultural livelihood in rural areas of Benin. This study improved the knowledge of people about the uses of $\boldsymbol{P}$. erinaceus organs connected to the sociolinguistic diversity in Benin, intending to enhance the pathways of conservation and sustainable management of the species. A total of 506 respondents from nine big sociolinguistic groups were interviewed using a survey questionnaire. To show the diversity of the organs/parts used as well as the categories of uses, principal component analyzes were performed to matrices including the relative frequencies of citation grouping the sociodemographic factors and the categories of uses, together under the packages FactoMineR and factoextra. The results revealed the use of all $P$. erinaceus organs in various forms of use for various purposes and make it an important species of livelihood for the local people. Sixty-four diseases, symptoms, or pathologies are cured by using $P$. erinaceus organs. These various uses of $P$. erinaceus varied among the sociolinguistic groups. The results of the study suggest the need to define conservation strategies for the natural stands of $P$. erinaceus to ensure sustainable management of the species.
\end{abstract}

Key words: Forest livelihoods, traditional uses, ethnomedicinal knowledge, conservation, principal component analysis, West Africa.

\section{INTRODUCTION}

To satisfy their staple needs, people strongly use plant species on which they depend. For that, many people value species as a source of food and medicine, providing means of subsistence and wealth to humans (IUCN Red List Committee, 2013). That leads scientists to be interested in the studies about traditional knowledge

\section{*Corresponding author. Email: bienvenuesourou@yahoo.fr.}


of plant species in consideration to socio-demographic, ecological, and botanical factors, such as sociolinguistic groups, livelihood activities, age, gender, habitats, areas of occurrence of species, etc. (Agbo et al., 2020; Wanjohi et al., 2020; Salako et al., 2018; Assogbadjo et al., 2008). Such studies have grown very interesting in sustainable management of endangered species because they allow assessing the differences of knowledge about the choice and use of plant resources by sociodemographic groups for defining priorities, planning, and monitoring conservation (Dovie et al., 2008). The ecological knowledge of people about plant species and their habitats could contribute to working out co-management strategies of plant resources for sustainable management of the environment (Wanjohi et al., 2020). Knowledge of local names facilitates the identification and assessment of species because they provide more information about the uses of species, ecology, plant interactions, and morphological traits (Agbo et al., 2020).

Pterocarpus erinaceus Poir is among those polyvalent species listed as endangered on the IUCN Red List (Barstow, 2018). It is also listed on CITES Appendix II since 2016. It is quite threatened throughout its distribution range because the wood has higher trade value (Dumenu, 2019; EIA, 2017). The leaves have higher nutrient quality and are used like fodder in ruminant breeding (Ouachinou et al., 2018; Rabiou et al., 2017a). Traditionally, the species is used in the treatment of many diseases, and symptoms in animals (Ouachinou et al., 2019; Dassou et al., 2015) and humans. Consequently, the natural stands have experienced decline and tend to extinction in several countries. The first affected countries were Benin, Guinea Bissau, Côte d'Ivoire, Gambia, Ghana, and Nigeria. Facing that issue, some exporting countries of the wood of $P$. erinaceus, including Benin, Burkina Faso, Côte d'Ivoire, Mali, Nigeria, and Sierra Leone have taken restrictions to forbid the wood logging and export for some years but, much quantity of the wood continues to quit these countries to China (EIA, 2017).

$P$. erinaceus occurs in Guinean savannahs of West Africa. Its distribution range stretches from the south to the north of Benin. It is found in the three ecological zones (Guinean, Guinean-Sudanese, and Sudanese zones) as natural stands in woodlands and savannahs. Though the banning of cutting and export of the timber, $P$. erinaceus is overexploited for other uses which bring about serious consequences on its relict stands as well as the environment. Currently, $P$. erinaceus is subjected to strong disturbances caused by the use forms of the organs in some regions of Benin while the previous studies on the traditional uses are mainly based on its potential in the treatment of diseases and symptoms in cattle (see Ouachinou et al., 2019, 2018; Dassou et al., 2015). Thus, the importance of the plant in the livelihood of people is still unappreciated. Agbani et al. (2018) reported that at Atakora Mountain Range, $P$. erinaceus is used by the people to substitute others threatened woody species, such as Khaya senegalensis (Desv.) A. Juss, Afzelia africana Smith ex Pers., Borassus aethiopum Mart., but they do not provide quite details about the local uses of $P$. erinaceus. That is required to understand the importance of the plant for the people life, its specific uses, and which potential risk for the conservation and restoration of relict stands. By spreading the study to the three ecological zones and several big sociolinguistic groups, we can provide detailed knowledge on the local uses of the species and additional insights on its forest livelihood potential. The study's purposes were to examine the various uses made with the organs of $P$. erinaceus in Benin connected to the sociolinguistic diversity, to enhance the body of knowledge in local practices on $P$. erinaceus, and to highlight the pathways for its conservation and sustainable management. Specifically, the study was designed to determine the (i) ethnoecological knowledge on $P$. erinaceus across the three ecological zones of Benin, (ii) uses made of the organs of $P$. erinaceus by the sociolinguistic groups, and (iii) implications of the local uses of the species on its conservation status.

\section{MATERIALS AND METHODS}

\section{Study area}

This study was conducted in the Republic of Benin, West Africa. It is bordered by the Atlantic Ocean to the south, Togo to the west, Nigeria to the east, Burkina Faso, and Niger to the north. The country covers a $114,763 \mathrm{~km}^{2}$ area, whose total population is $10,008,749$ inhabitants, making a population density of 87.2 inhabitants per square kilometer (INSAE, 2013). Although it is a sub-Saharan country in the eastern part of the Guinean Dense Humid Forests Ecoregion, it is outside the natural ranges of the Diversity Centres of Upper and Lower Guinea. The surveys were conducted across eighteen townships out of seventy-seven: Covè, Bohicon, Abomey (in the Guinean zone), Djidja, Dassa, Savalou, Bantè, Glazoué, Savè, Ouèssè, Tchaourou, Parakou, Kalalé (in the Guinean-Sudanese zone), Péhunco, Ségbana, Kandi, Malanville, Djougou (in the Sudanian zone). The total population in these eighteen townships is 2,794,728 inhabitants, corresponding to $27.92 \%$ out of the total population of Benin. The Figure 1 shows an overview of the study area.

\section{Sampling and data collection}

Data were collected from September to November 2018. The eighteen townships considered for the study were picked out based on the local distribution range and the abundance of the target species. Nine sociolinguistic groups were surveyed across the eighteen townships. The sample size was calculated per sociolinguistic group. Preliminary surveys with fifty respondents picked out at random per sociolinguistic group enabled us to determine the proportion (p) out of respondents who know $P$. erinaceus and directly use it, or its organs as a source of livelihoods, such as selling of organs, food, medicine, fodder, or any other uses for specific purposes. Thereafter, the number of respondents in each sociolinguistic group was calculated as follows (Levy and Lemeshow, 2008; Dagnelie, 1998): 


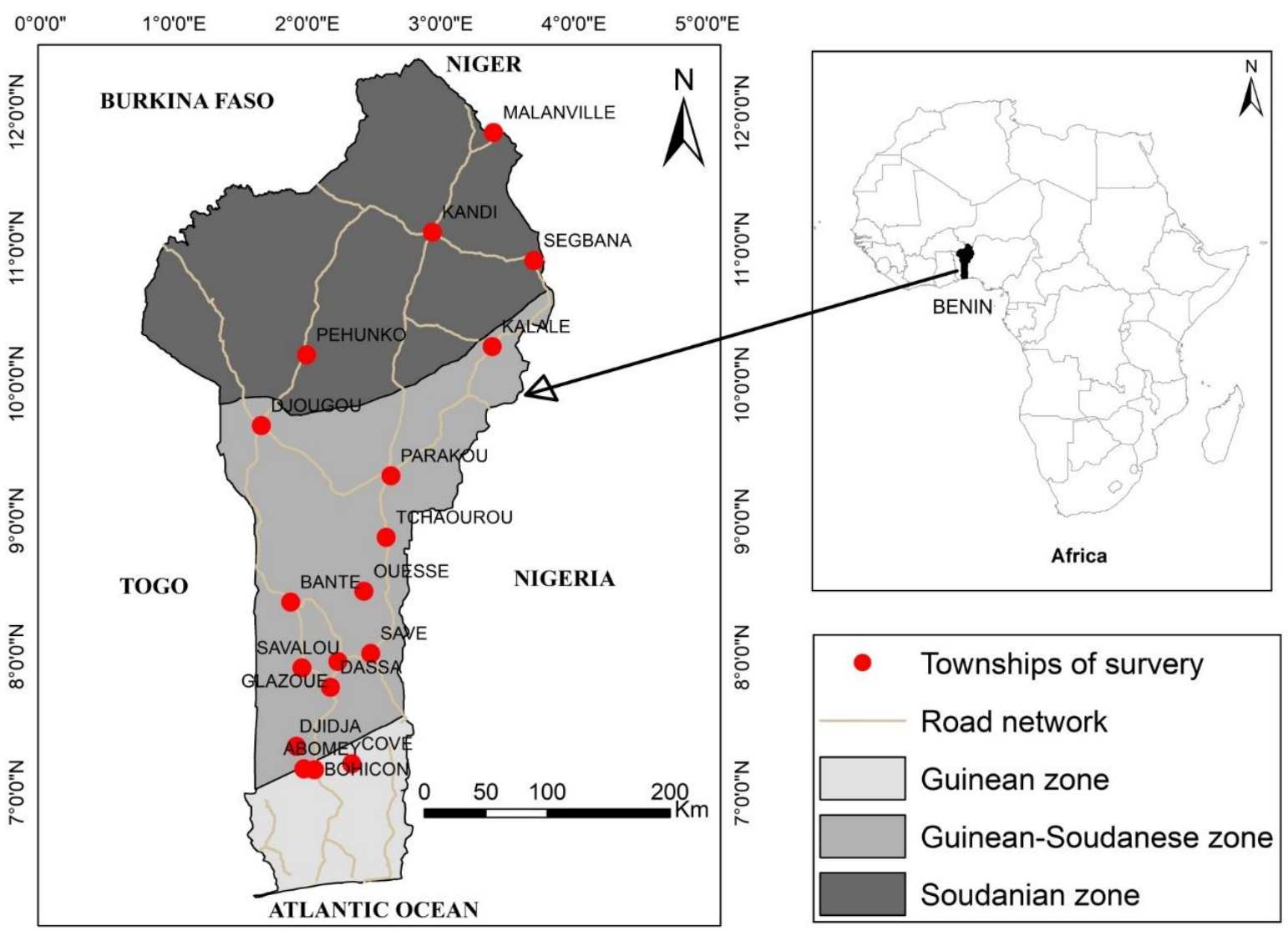

Figure 1. Location of the country and townships of the study.

$N=\left[U_{(1-\alpha / 2)}^{2} / d^{2}\right] \times[p(1-p)]$

$N$ is the sample size per sociolinguistic group, $p$ is the proportion of respondents who use the plant in each sociolinguistic group, computed after the preliminary surveys, $d=9 \%$ is the sampling error admitted, and $U_{(1-\alpha / 2}$ is the normal random variable (with $\alpha=$ $\left.5 \%, U_{(1-\alpha / 2)}=1.96\right)$. The proportion of respondents on the sociolinguistic groups Nago and Fon were $p=0.88$ and 0.76 , respectively. That means $N=50$ and 87 respondents were interviewed on the sociolinguistic groups Nago and Fon, respectively. The same approach was used to determine the sample size for the other sociolinguistic groups (Table 1). A total of five hundred and six (506) respondents were surveyed across the three ecological zones.

\section{Data analysis}

Data analysis was carried out based on five factors: ecological zones (EZ); sociolinguistic groups; age; gender; and livelihood activities. Three age classes were made according to Assogbadjo et al. (2008): young respondents (age $\leq 30$ years); adult respondents ( $30<$ age $<60$ ); old respondents (age $\geq 60$ years). To describe the people's perception of the ecology (habitat) of $P$. erinaceus, we performed the chi-square test of independence on the $n \times p$ matrix (with $n$ the ecological zones, and $p$ the habitats of the species). The relative frequencies of citation (RFC) (Salako et al., 2018; Houehanou et al., 2011; Tardío and Pardo-de-Santayana, 2008) for each habitat were then calculated to describe the habitat variation according to the EZ using the following formula:

$R F C=x / N$

$x$ is the absolute frequency and $N$ is the total number of respondents for each modality of the considered factor (eg: $x=20$ and $N=100$ to mean twenty respondents out of one hundred respondents specified woodland as habitat of $P$. erinaceus).

To highlight the categories of uses and the most organs/parts reported, multiple proportion comparison tests were performed and proportions were structured under the libraries multcompView (Graves et al., 2019) and PMCMR (Pohlert, 2014). We performed principal component analyses to describe the diversification of the categories of uses, such as human food (as a vegetable), animal food (as fodder), handicraft, carbonization, timber, firewood, and symbolic uses in traditional ceremonies such as dowry. We used the matrices comprising the RFC grouping the socio-demographic factors (sociolinguistic group, gender, age, and livelihood activities) and the categories of uses, together under the libraries FactoMineR (Le et al., 2008) and factoextra (Alboukadel and Mundt, 2020). All statistical analyses were performed in $R$ software version 3.6.0 ( $R$ Core Team, 2019). 
Table 1. Number of respondents per sociolinguistic group in the eighteen townships.

\begin{tabular}{|c|c|c|c|c|c|}
\hline \multirow{2}{*}{$\begin{array}{l}\text { Sociolinguistic } \\
\text { groups }\end{array}$} & \multirow{2}{*}{$\begin{array}{l}\text { Local names of } P \text {. } \\
\text { erinaceus }\end{array}$} & \multirow{2}{*}{ Townships } & \multicolumn{3}{|c|}{ Sample size } \\
\hline & & & $p$ & $N$ & Relative frequencies (\%) \\
\hline Fon & Kosso/Kozo & Abomey, Bohicon, Covè, Djidja & 0.76 & 87 & 17.13 \\
\hline Dendi & Tolo & Djougou, Malanville, Parakou & 0.78 & 81 & 16.12 \\
\hline Idaatcha & Akpékpé & Dassa & 0.80 & 76 & 15.03 \\
\hline Boo & Kpinli & Ségbana & 0.84 & 64 & 12.62 \\
\hline Bariba & Tonan & Kandi, Parakou & 0.86 & 57 & 11.31 \\
\hline Nago & Egui-Enian/Aïkpé & Savè, Tchaourou & 0.88 & 50 & 09.92 \\
\hline Itcha & Akpékpé & Bantè & 0.90 & 44 & 08.71 \\
\hline Mahi & Kosso & Glazoué, Savalou, Ouèssè & 0.94 & 27 & 05.30 \\
\hline Peulh & Banouhi & Kalalé, Péhunco & 0.96 & 20 & 03.96 \\
\hline Total & & & & 506 & 100.00 \\
\hline
\end{tabular}

$p$ : Proportion of respondents who know Pterocarpus erinaceus and directely use it, or its organs as a source of livelihood, $N$ : sample size.

\section{RESULTS}

\section{Sociodemographic and economic characteristics of the respondents}

Table 2 shows the sociodemographic and economic characteristics of the respondents. The number of male respondents was $428(84.58 \%)$ while the number of female respondents was 78 (15.42\%). Regarding the ecological zones, a great number of respondents lived in Guinean-Soudanese $(39.72 \%$ males and $7.51 \%$ females $)$ and Soudanian $(32.21 \%$ males and $6.13 \%$ females) zones. Regarding the age, $36.17 \%$ of respondents were between 30 and 60 years old while $48.81 \%$ of respondents were $>60$ years old. Regarding the livelihood activities, seven categories were considered. Farmers $(39.92 \%)$ and traditherapists $(36.17 \%)$ were the majority while the nurserymen were the minority $(2.17 \%)$. Regarding the sociolinguistic groups, Fon, Dendi, Idaatcha, Boo, and Bariba were the majority while the sociolinguistic groups Mahi and Peulh were the minority (Table 2).

\section{Ethnoecological knowledge on Pterocarpus erinaceus}

According to the respondents, $P$. erinaceus occurred in woodlands $(44.8 \%$ of respondents), farms $(34.82 \%$ of respondents), fallows (15.56\%), and savannahs (4.78\%). However, woodlands and savannahs were suitable habitats known in ancient times. People's perceptions of the species' habitat differed significantly among ecological zones $(x 2=81.91$, df $=6$, Prob. $<0.001)$. Thus, whatever the ecological zone, the respondents indicated that farms and forests were suitable habitats. Additionally, the people living in the Sudanian, and the Guinean-Soudanese zones have also mentioned fallows as a suitable habitat. In the Guinean-Soudanese zone, the respondents exclusively mentioned savannahs as a suitable habitat for the species.

\section{Traditional uses of Pterocarpus erinaceus and their importance for the livelihood of people}

$P$. erinaceus is known and directly used as a medicinal plant for fifty-seven pathologies, symptoms, and diseases listed by respondents (Table 3). However, knowledge on the use of the species in traditional medicine varied among the sociolinguistic groups. The plant is used to cure numerous human health disorders, including malaria, fever, hernia, anemia, metrorrhagia, menstrual pain, irregular menses, abscess, hemorrhoid, headaches, stomach hurt, tooth decay, mental disorders, skin infections, oedema, paralysis of limbs, sight troubles, women infertility, gastric ulcer, intestinal worms, general tiredness, typhoid fever, dizziness, urinary tract infections (Table 3). Leaves, barks, and roots were the organs used more in traditional medicine. The sociolinguistic group Peulh used the barks and roots to treat wounds, colic, constipation, viral anemia, diarrhea, calving difficulties, hemorrhage, infectious disorders, toothache, the bite of a snake, peripneumonia, and for giving cattle an appetite (Table 3). The sociolinguistic group Itcha used the plant to treat infections and measles while the sociolinguistic group Boo used the plant to treat abscess, acne pimples, whitlow, and stings of the scorpion. The sociolinguistic group Bariba used the plant to treat ringworm and wounds while sociolinguistic group Dendi used it to treat the bite of snake in cattle, stings of the scorpion, and sight troubles. In addition, Bariba, Nago, and Boo reported that leaves, roots, and bark were used for evil spirits, and to prevent bewitchments. These organs are particularly used by Bariba for wedding officiation to ensure peace and love in the households (Table 3 ). 
Table 2. Sociodemographic and economic characteristics of the respondents.

\begin{tabular}{|c|c|c|c|c|c|}
\hline \multirow{2}{*}{ Variable } & \multirow{2}{*}{ Modalities } & \multicolumn{3}{|c|}{ Ecological zones } & \multirow[b]{2}{*}{ Total (\%) } \\
\hline & & Guinean & Guinean-Soudanese & Soudanian & \\
\hline \multirow{2}{*}{ Gender } & Females & $9(1.78)$ & $38(7.51)$ & $31(6.13)$ & $78(15.42)$ \\
\hline & Males & $64(12.65)$ & $201(39.72)$ & $163(32.21)$ & $428(84.58)$ \\
\hline \multirow{3}{*}{ Age (years) } & Young: $<30$ & $14(2.77)$ & $37(7.31)$ & $25(4.94)$ & $76(15.02)$ \\
\hline & Adult: 30 - 60 & $31(6.13)$ & $117(23.12)$ & $99(19.57)$ & $247(48.81)$ \\
\hline & Old: $>60$ & 49(9.68) & $83(16.40)$ & $51(10.08)$ & $183(36.17)$ \\
\hline \multirow{7}{*}{$\begin{array}{l}\text { Livelihood } \\
\text { activities }\end{array}$} & Farming & $26(5.14)$ & $92(18.18)$ & $84(16.60)$ & 202(39.92) \\
\hline & Traditional medicine (Traditherapists) & $16(3.16)$ & $51(10.08)$ & $116(22.92)$ & 183(36.17) \\
\hline & Charcoal production & $6(1.19)$ & $13(2.57)$ & $20(3.95)$ & $39(7.71)$ \\
\hline & Logging (Sawyers) & $4(0.79)$ & $9(1.78)$ & $13(2.57)$ & $26(5.14)$ \\
\hline & Carpenters & $11(2.17)$ & $5(0.99)$ & $9(1.78)$ & $25(4.94)$ \\
\hline & Cattle breeding & $3(0.59)$ & $7(1.38)$ & $10(1.98)$ & $20(3.95)$ \\
\hline & Forest plants production (Nurserymen) & $2(0.40)$ & $5(0.99)$ & $4(0.79)$ & $11(2.17)$ \\
\hline \multirow{9}{*}{$\begin{array}{l}\text { Sociolinguistic } \\
\text { groups }\end{array}$} & Fon & $68(13.44)$ & $19(3.75)$ & - & $87(17.19)$ \\
\hline & Dendi & - & $24(4.74)$ & $57(11.26)$ & $81(16.01)$ \\
\hline & Idaatcha & - & $62(12.25)$ & $14(2.77)$ & $76(15.02)$ \\
\hline & Boo & - & - & $64(12.65)$ & $64(12.65)$ \\
\hline & Bariba & - & $13(2.57)$ & $44(8.70)$ & $57(11.26)$ \\
\hline & Nago & - & $45(8.90)$ & $5(0.99)$ & $50(9.88)$ \\
\hline & Itcha & - & $44(8.70)$ & - & $44(8.70)$ \\
\hline & Mahi & $2(0.40)$ & $25(4.94)$ & - & $27(5.34)$ \\
\hline & Peulh & $3(0.59)$ & $7(1.38)$ & $10(1.98)$ & $20(3.95)$ \\
\hline
\end{tabular}

Values without brackets are numbers of respondents and values in brackets are percentages of respondents. Dashs in the table indicate no respondent.

\section{Sociodemographic factors influencing the uses of Pterocarpus erinaceus}

The frequencies of citation of the use categories differed significantly $\left(X^{2}=967.93, \mathrm{ddl}=7\right.$, Prob. $<0.001$; Table 4). Thus, respondents primarily used the species like timber and service wood $(25.66 \%$ and $25.41 \%$ as RFC values, respectively; Figure 2). They also make use of it for medicinal purposes and fodder sources in cattle $(20.96 \%$ and $19.67 \%$ as RFC values, respectively; Figure 2). In addition, there was dependence of the use categories with the ecological zones (EZ), gender, sociolinguistic groups, and livelihood activities of the respondents (Prob. $<0.05)$. Thus, only men used $P$. erinaceus in handicrafts. The uses like firewood and lumber had the same importance for both men and women. On the other hand, men used more of the species for charcoal production while women used its leaves in food, like a vegetable. The use of handicraft was noted in both GuineanSudanese and Sudanian zones while the symbolic use was noted in both Guinean and Guinean-Sudanese zones. The use as food in humans was noted exclusively in Guinean-Sudanese zone.
Principal component analysis (PCA) performed on the RFC of the use categories and sociolinguistic groups showed that the first two PC saved $85.7 \%$ of the initial information (Figure 3a). The use categories, such as food (vegetable and fodder), firewood, timber (technology), and handicraft were correlated strongly (| Correlation $\mid \geq$ 0.5) with the first PC while carbonization (charcoal production) correlated with the second PC. Thus, the projection of the sociolinguistic groups into the two $\mathrm{PC}$ showed that the sociolinguistic groups Bariba, Boo, Dendi, Fon, Itcha, and Mahi used more P. erinaceus like vegetable (for human food), fodder, firewood, timber, and handicraft whereas the sociolinguistic group Idaatcha used more of it for carbonization (Figure 3a). On the other hand, the PCA performed on the RFC of the use categories and livelihood activities showed that the first two PC saved $61.3 \%$ of the initial information (Figure $3 b$ ). The use categories, such as timber, firewood, carbonization, and human food were correlated strongly (| Correlation | $\geq 0.5$ ) with the first PC while the use for animal food correlated with the second PC. The projection of the livelihood activities into the two PC showed that charcoal makers, farmers, and lumberjacks 
Table 3. Traditional knowledge and medicinal importance of Pterocarpus erinaceus through the sociolinguistic groups surveyed in Benin.

\begin{tabular}{|c|c|c|c|}
\hline $\begin{array}{l}\text { Local uses for diseases, } \\
\text { symptoms or pathologies }\end{array}$ & Organs / parts & Use categories & Sociolinguistic groups \\
\hline Abortion & Barks, leaves, roots & Medicinal & Bariba, Boo \\
\hline Abscess & Barks, leaves, sap & Medicinal & Bariba, Boo, Mahi \\
\hline Acne pimples & Sap & Medicinal & Boo \\
\hline Anemia & Barks, leaves, roots & Medicinal & Bariba, Peulh, Dendi, Nago, Boo, Mahi, Fon, Idaatcha, Itcha \\
\hline Asthenia in human and cattle & Barks, roots, leaves & Medicinal, veterinary & Peulh, Boo \\
\hline Babies fontanel & Roots & Medicinal & Bariba \\
\hline Bewitchment & Barks, roots, leaves & Magic & Peulh, Nago, Boo \\
\hline Bite of snake & Barks & Veterinary & Peulh, Dendi, Boo \\
\hline Bloated belly & Barks & Medicinal, veterinary & Boo \\
\hline Calving difficulties & Barks & Veterinary & Peulh \\
\hline Colic in cattle & Barks & Veterinary & Peulh \\
\hline Constipation in cattle & Barks & Veterinary & Peulh \\
\hline Cough & Barks & Medicinal & Nago, Boo \\
\hline Couple union & Barks & Magic & Bariba \\
\hline Dental carrie & Barks, leaves & Medicinal & Bariba, Dendi \\
\hline Diabetes & Barks, roots, leaves & Medicinal & Nago, Fon, Itcha \\
\hline Diarrhea in human and cattle & Leaves, barks & Medicinal, veterinary & Peulh, Boo, Itcha \\
\hline Dizziness & Barks, leaves & Medicinal & Bariba \\
\hline Emaciation in cattle (Loss in weight) & Barks, leaves, roots & Fodder, veterinary & Bariba, Peulh \\
\hline Evil spirits & Barks & Magic & Bariba, Dendi, Nago \\
\hline Fever & Barks, leaves & Medicinal & Bariba, Dendi, Nago, Mahi, Fon, Idaatcha \\
\hline Gastric ulcer & Barks, roots & Medicinal & Bariba, Dendi, Nago \\
\hline Gonorrhea & Roots, leaves, barks & Medicinal & Bariba, Mahi, Itcha \\
\hline Headache & Barks, leaves & Medicinal & \\
\hline Hemorrhage in cattle & Barks, leaves, roots & Veterinary & Bariba, Peulh, Dendi \\
\hline Hemorrhoid & Barks, leaves, roots & Medicinal & Bariba, Peulh, Dendi, Fon, Idaatcha, Itcha \\
\hline Hernia & Barks, leaves, roots & Medicinal & Bariba, Idaatcha \\
\hline High blood pressure & Leaves & Medicinal & Mahi \\
\hline Hypertension & Barks, roots & Medicinal & Peulh \\
\hline Hypotonia in children & Barks, roots & Medicinal & Peulh, Dendi, Nago, Mahi, Fon, Idaatcha \\
\hline Infectious disorders & Barks, sap & Medicinal, Veterinary & Peulh, Dendi, Nago, Mahi, Itcha \\
\hline Infertility in women & Barks, roots & Medicinal & Peulh, Mahi, Fon, Itcha \\
\hline Intestinal worms & Barks, roots & Medicinal, veterinary & Bariba, Peulh, Itch \\
\hline Irregular menstruation & Barks & Medicinal & Bariba, Dendi, Nago, Boo, Mahi \\
\hline Itching & Barks, roots, leaves & Medicinal & Nago, Itcha \\
\hline Leprosy & Barks & Medicinal & Mahi \\
\hline Lower abdomen pain & Roots & Medicinal & Itcha \\
\hline Malaria & Barks, roots, leaves & & Peulh, Dendi, Boo, Mahi, Fon, Itcha \\
\hline Mange in cattle & Leaves & Veterinary & Peulh \\
\hline Measles & Barks, roots, sap & Medicinal & Nago, Mahi, Idaatcha, Itcha \\
\hline Menstrual pain & Barks, leaves, roots & Medicinal & Bariba, Peulh, Dendi, Boo, Mahi, Idaatcha, Itcha \\
\hline Mental disorders & Barks, leaves & Medicinal & Bariba \\
\hline Metrorrhagia & Barks, leaves & Medicinal & Bariba, Dendi \\
\hline Oedema & Barks, leaves, roots & Medicinal & Bariba \\
\hline Paralysis of the lower limbs & Barks, leaves & Medicinal & Bariba \\
\hline Pleuropneumonia in cattle & Barks & Veterinary & Peulh \\
\hline Ringworm & Sap & Medicinal & Bariba, Peulh \\
\hline Rheumatism & Roots & Medicinal & Boo \\
\hline Sickle cell & Leaves, roots & Medicinal & Peulh, Fon \\
\hline Sight troubles & Barks, roots, sap & Medicinal & Bariba, Peulh, Dendi, Nago \\
\hline
\end{tabular}


Table 3. Contd.

\begin{tabular}{llll}
\hline Skin infections & Barks, leaves, sap & Medicinal & Bariba, Peulh, Dendi \\
Spoiling of appetite & Barks & Veterinary & Peulh, Boo \\
Stings of scorpion & Sap, roots & Medicinal & Dendi, Boo \\
Stomach hurt & Barks, leaves, roots & Medicinal & Bariba, Peulh, Dendi, Mahi, Fon, Idaatcha, Itcha \\
Teething & Barks, roots & Medicinal & Dendi, Fon \\
Tiredness & Barks, leaves, roots & Medicinal & Bariba, Peulh, Nago, Mahi, Fon, Idaatcha, Itcha \\
Tooth hurt & Barks & Medicinal & Peulh \\
Typhoid fever & Barks, leaves & Medicinal & Bariba \\
Urinary tract infections & Barks, leaves & Medicinal & Bariba \\
Vaginal bleeding & Roots, leaves & Medicinal & Bariba, Boo \\
Viral diarrhea in cattle & Barks & Veterinary & Peulh \\
Virility & Roots & Medicinal & Nago, Boo, Fon \\
Whitlow & Sap & Medicinal & Boo \\
Wounds & Sap, barks & Medicinal & Bariba, Peulh, Mahi \\
\hline
\end{tabular}

Table 4. Dependence of the frequencies of citation with use categories and sociodemographic factors.

\begin{tabular}{lccc}
\hline Sociodemographic factors & Df & $\mathbf{X}^{\mathbf{2}}$ & P-value \\
\hline Ecological zone & 12 & 58.27 & $<0.001$ \\
Age & 12 & 13.92 & 0.306 \\
Gender & 06 & 19.99 & 0.003 \\
Sociolinguistic group & 48 & 80.21 & 0.002 \\
Livelihood activities & 48 & 115.05 & $<0.001$ \\
\hline
\end{tabular}

used more $P$. erinaceus for carbonization, firewood, and timber while breeders used more of it as fodder for feeding cattle (Figure 3b).

\section{Uses of the organs of Pterocarpus erinaceus accross the sociolinguistic groups}

The most organs harvested are the trunks (25.43\%), branches (23.90\%), leaves (23.14\%), and barks (22.09\%) (Figure 4).

Figure 5 shows the results of the PCA performed on the RFC of the organs of $P$. erinaceus and the sociodemographic factors. It shows that the first two PC saved $70 \%$ of the initial information on the sociodemographic factors and the organs of the species. The correlation matrices show a strong correlation (|Correlation| $\geq 0.5$ ) among both the Guinean and Sudanian zones and the first PC while the GuineanSoudanese zone correlated with the second PC. Thus, the projection of the organs into the first two PC showed that the trunk, leaves, barks, branches, and seeds were the most organs used in both the Guinean and Sudanian zones while the roots and latex were used more in the Guinean-Sudanese zone (Figure $5 \mathrm{a}$ ). Figure $5 \mathrm{~b}$ shows that both young and adult categories of age correlated strongly (|Correlation| $\geq 0.5$ ) with the first PC while the category old correlated with the second PC. Thus, the projection of the organs into the two PC showed that the trunk, leaves, roots, branches, seeds, and latex were heavily harvested by young and adult respondents while barks were sought more by old respondents (Figure $5 b$ ). Regarding the sociolinguistic groups, Bariba, Boo, Peulh, Dendi, Mahi, and Nago correlated strongly with the first PC while Itcha correlated with the second PC and Fon with the third PC. Thus, the projection of the organs into the first three PC showed that the trunk, leaves, barks, and branches were the most organs used by Bariba, Boo, Peulh, Dendi, Mahi, and Nago while both the roots and latex were used more by Itcha, and the seeds were used more by Fon (Figure $5 c$ and d). Figure $5 e$ shows that the livelihood activities, traditional medicine (traditherapists), and logging (sawyers) correlated strongly with the first PC while both farming (farmers) and forest plants production (nurserymen) correlated strongly with the second PC. The projection of the organs into the two PC showed that the trunk, leaves, barks, and branches were used more by the respondents who practice traditional medicine and logging while farmers and nurserymen used more of the roots (Figure $5 e$ ). 


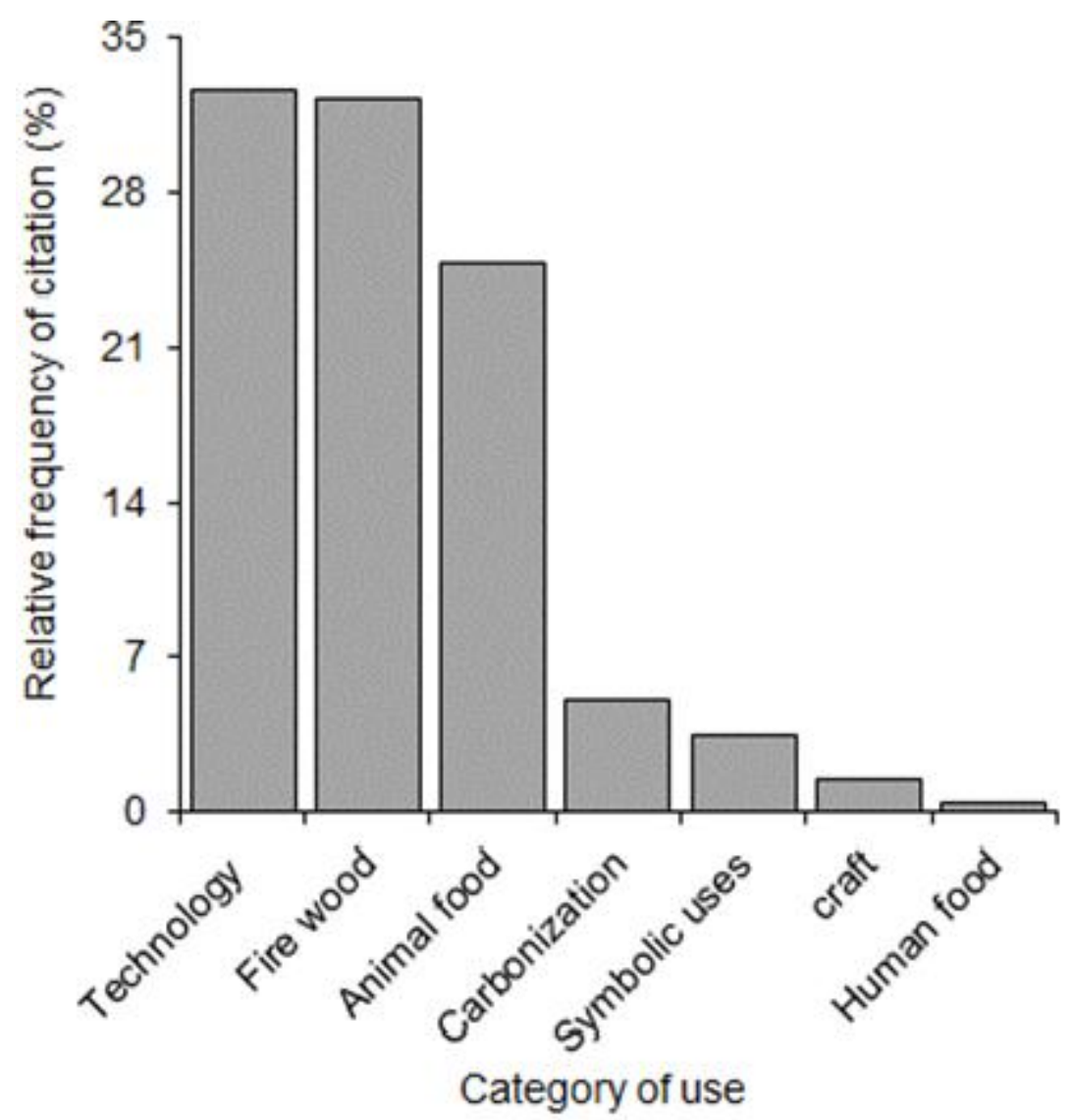

Figure 2. Importance of the use categories of Pterocarpus erinaceus for the respondents.
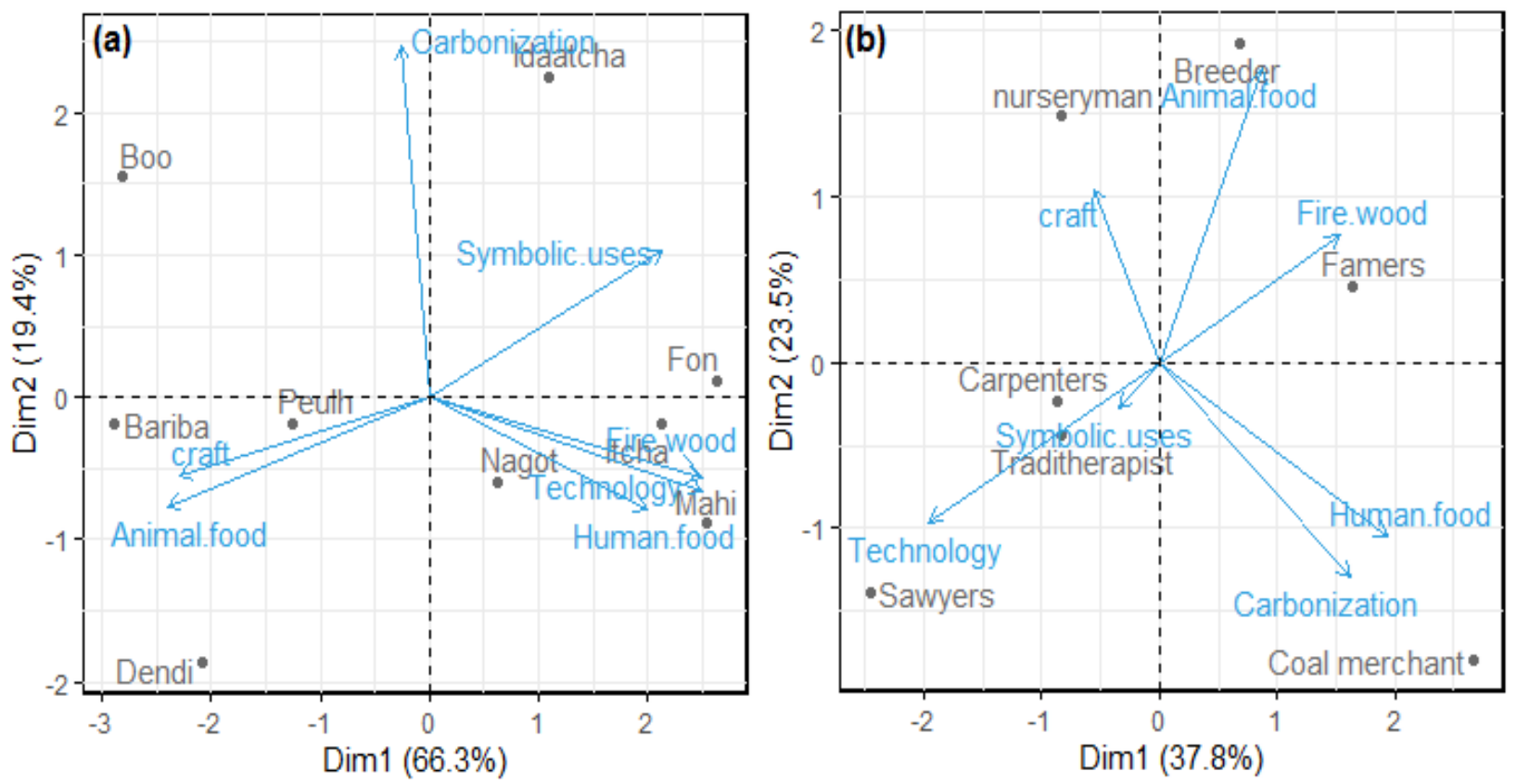

Figure 3. Relationship among the sociolinguistic groups (a), livelihood activities (b), and the use categories of Pterocarpus erinaceus. 


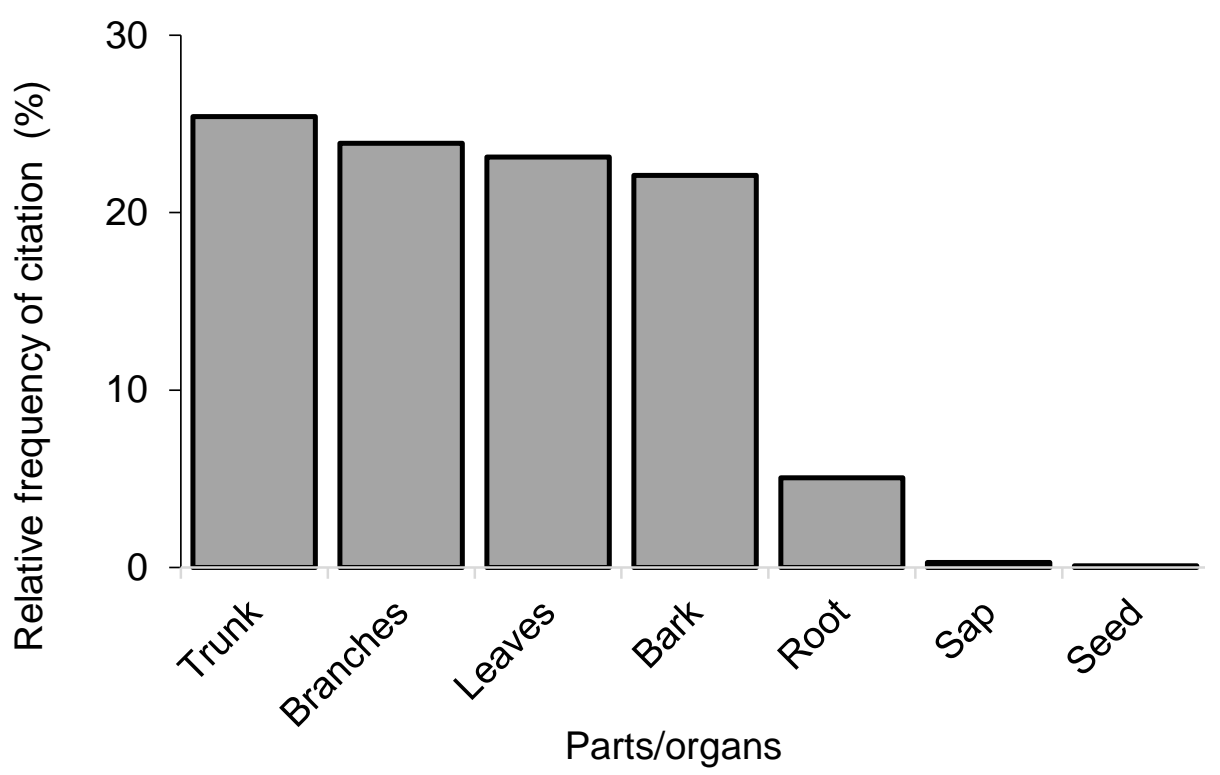

Figure 4. Relative importance of the organs of Pterocarpus erinaceus harvested by the respondents.

\section{DISCUSSION}

\section{Implication of the traditional uses of Pterocarpus erinaceus in people's livelihood}

$P$. erinaceus is a valuable species of forest livelihood for local people. This study enabled us to identify seven categories of uses and sixty-four diseases, symptoms, or pathologies for which the organs of the species are harvested. Some local uses and traditional knowledge on $P$. erinaceus are part of the ones noted in Niger, Burkina Faso (Rabiou et al., 2017a), and Togo (Sègla et al., 2015a) on the same species. Apart from the local uses reported in these studies, many other uses are revealed in this study. More than thirty supplementary diseases, symptoms, and pathologies cured by using the organs of $P$. erinaceus are reported, whose abortion, abscess, acne pimples, asthenia in humans and cattle, baby's fontanel, the bite of a snake, cough, couple union, diabetes, dizziness, gonorrhea, hernia, hypertension, infectious disorders, infertility in women, intestinal worms, leprosy, metrorrhagia, teething, whitlow, ringworm, and pleuropneumonia in cattle. To treat these diseases, symptoms, or pathologies, people use the bark, roots, leaves, and sap. This medicinal property of the organs of $P$. erinaceus is reported by Gbohaïda et al. (2015) and Tittikpina et al. (2013) who revealed in the roots, barks, and leaves of $P$. erinaceus, the presence of chemicals (flavonoids, saponins, and alkaloids) with antifungal and antibacterial effects. Also, Ouédraogo et al. (2012) revealed in the organs of $P$. erinaceus, the presence of friedeline, a compound with anti-tumor, anti-inflammatory, anti-analgesic, and antipyretic effects.
The wood of the species is strongly sought by carpenters, joiners, and craftsmen in construction and for making movables, such as tables, chairs, closets, doors, windows, mortars, butts, the haft of farming tools, and musical instruments, whose sale provided them livelihood income. The leaves, barks, and roots are sold by women in markets and contribute to livelihood income for many households. All the respondents perceived $P$. erinaceus as an important source of forest livelihoods. The "Tamaré", a powder made with the heartwood is used by the sociolinguistic group Peulh for evil spirits to protect children specifically. The wood sized $2.2 \mathrm{~m}$ long and 20$25 \mathrm{~cm}$ width is sold like the timber, whose sale price varied from XOF12,000 (\$21.48) to XOF25,000 (\$44.75) according to the regions. The leaves are bound and sold at XOF50 (\$0.09) or XOF100 $(\$ 0.18)$ through the rainy season and XOF150 (\$0.27) through the dry season. The barks and roots which are more and more expensive are also bound and sold to XOF150 (\$0.27) or XOF200 $(\$ 0.36)$ according to the regions. The respondents declared that incomes are used for own or family needs, such as school fees, clothing, and construction. In the international markets of Glazoué and Malanville, we noted that the leaves and barks are exported to Nigeria and Burkina Faso. Apart from the uses in traditional medicine, joinery, arts, and crafts, $P$. erinaceus is also used for firewood and charcoal production. Furthermore, the uses on $P$. erinaceus allow the respondents to improve their livelihood sources. Most of the respondents reported that the quantity of the organs (wood, leaves, barks, and roots) that they harvested to provide for their subsistence has decreased drastically because of the species scarcity. That poses threats to health and 

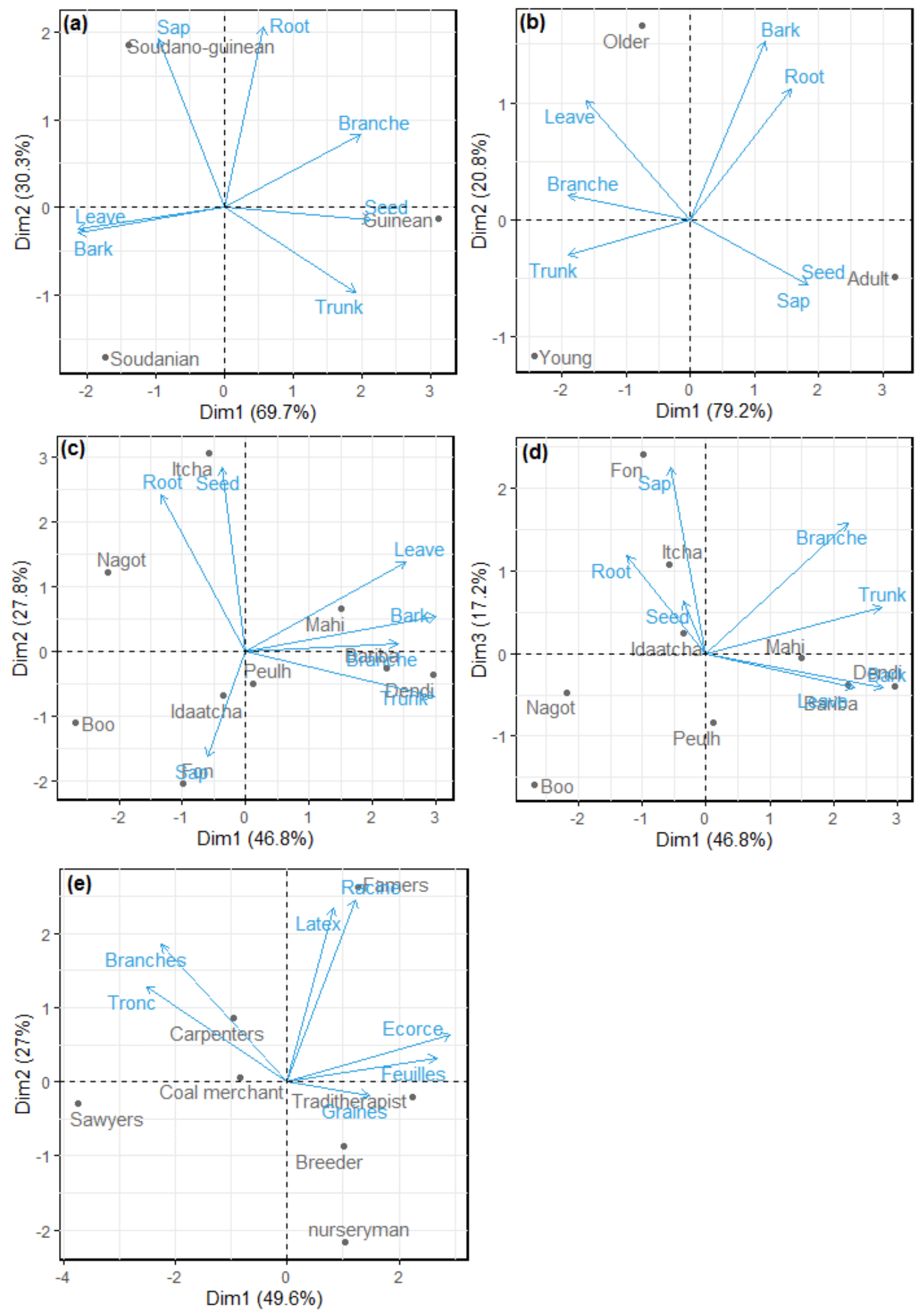

Figure 5. Relationship among local uses of the organs of Pterocarpus erinaceus and the (a) ecological zones, (b) age (c \& d) classes, sociolinguistic groups, and (e) livelihood activities. 
livelihood activities for people and fodder for cattle. The leaves constitute an important source of fodder for cattle in the dry season because they contain a high proportion of crude protein, organic matter, fibers, and mineral elements for keeping health in cattle (Nantoumé et al., 2018). The use of wood more extensively for the livelihood activities, such as carpentery, joinering, arts and crafts is linked to its better physical and mechanical properties (density and hardness) compared to other timber species (Sègla et al., 2017, 2015b).

\section{Relationship among the uses of Pterocarpus erinaceus and the sociodemographic factors}

The results showed that traditional knowledge on the uses of the organs of $P$. erinaceus depend on ecological zone, sociolinguistic group, gender and livelihood activity. The use on $P$. erinaceus for handicraft and charcoal production by men could be justified by the fact that these activities are carried out by men while cooking is the appanage of women in households. That would justify women's knowledge on the use of the species in food like vegetable. Predominance of handicraft use in GuineanSudanese and Sudanian zones is linked to the fact that there are more craftsmen in these zones. The uses of leaves like vegetable in Guinean-Sudanese zone is linked to the fact that this culinary recipe is a particular of the sociolinguistic groups Itcha in Bantè and Nago in Savè, two townships located in Guinean-Sudanese zone. The distribution of the categories of uses in relation to the ecological zones is therefore linked to the traditional knowledge of the sociolinguistic groups who are living there. The harvesting capacity on the organs also depends on the livelihood activities and traditional knowledge of the sociolinguistic groups in each ecological zone. Indeed, the strong use of leaves and barks by the sociolinguistic groups Peulh, Dendi, and Bariba in Sudanian zone is linked to the dominance of the practice of ruminant breeding in this part of Benin.

\section{Impacts of the traditional uses of Pterocarpus erinaceus on the conservation of the species in Benin}

The leaves are used to feed cattle and sheep while the barks and roots are often used to treat many diseases in humans and animals. On this fact, the trees of $P$. erinaceus are often pruned in forests, farms, fallows, wherever the species is found in Benin (Figure 6). The strongly anthropogenic pressures exerted on the natural stands decreased drastically the survival chance of the species. The frequently pruning on the trees drove to irregular fructification and threatens the availability of the seeds. The barking affects the plant's growth slowly threatening the availability of the wood. According to Adjonou et al. (2010) in Togo, uncontrolled and repeated harvesting of the organs of $P$. erinaceus for livelihood activities such as farm, breeding, and traditional medicine as well as the bad harvesting practices of the species affected seriously the plant growth and the natural regeneration. The strong pressures exerted on $P$. erinaceus by humans mean that the species is very important for the livelihood of people. Despite the importance of $P$. erinaceus in Benin, the species did not receive sustained attention for the sustainable management of the natural stands.

\section{Pathways for conservation and sustainable management of Pterocarpus erinaceus in Benin}

The legal protection enjoyed by $P$. erinaceus in Benin through the prohibition of logging and timber exportation, its inclusion on CITES Appendix II, and conservation status on the IUCN Red List as endangered (EN) species are not sufficient for its sustainable management. It therefore appears imperative that additional conservation and restoration strategies be taken to preserve the species in Benin. Regarding the current conservation status of $P$. erinaceus and the quickness degradation of the natural stands, it is advisable to combine both in-situ and ex-situ conservation forms as urgent conservation and restoration strategies to keep the genetic diversity of $P$. erinaceus and to ensure its survival. A key strategy for the conservation of $P$. erinaceus could be improved habitat management to enable connectivity among the relict populations. Agroforestry systems, if well managed, could help to establish this connectivity across the landscape by playing the role of biological corridors among populations (Ouinsavi and Sokpon, 2008). Relict populations of the species which should be a high conservation priority as well as protected areas in savannah regions could also serve as a corridor among the planting plots of the species. This method of conservation was already proposed for the relict populations of Milicia excelsa Welw. Cc. berg) in Benin (Ouinsavi et al., 2009; Ouinsavi and Sokpon, 2008). Assogbadjo (2006) qualifies it as "ex-situ conservation on-farm" for natural stands of Adansonia digitata L. in Benin. Practically, this strategy will consist of conserving plots containing $P$. erinaceus, cultivated within the ecological niche of the species so that the young populations establish a bridge in terms of gene flow among various sub-populations. Thus, the research work carried out by Johnson et al. (2020), Ouinsavi et al. (2019), and Rabiou et al. (2017b) on the isolation of microsatellites and vegetative propagation of $P$. erinaceus, respectively, could serve as a basis to ensure the species preservation.

\section{Conclusion}

This study revealed many other uses of $P$. erinaceus in 


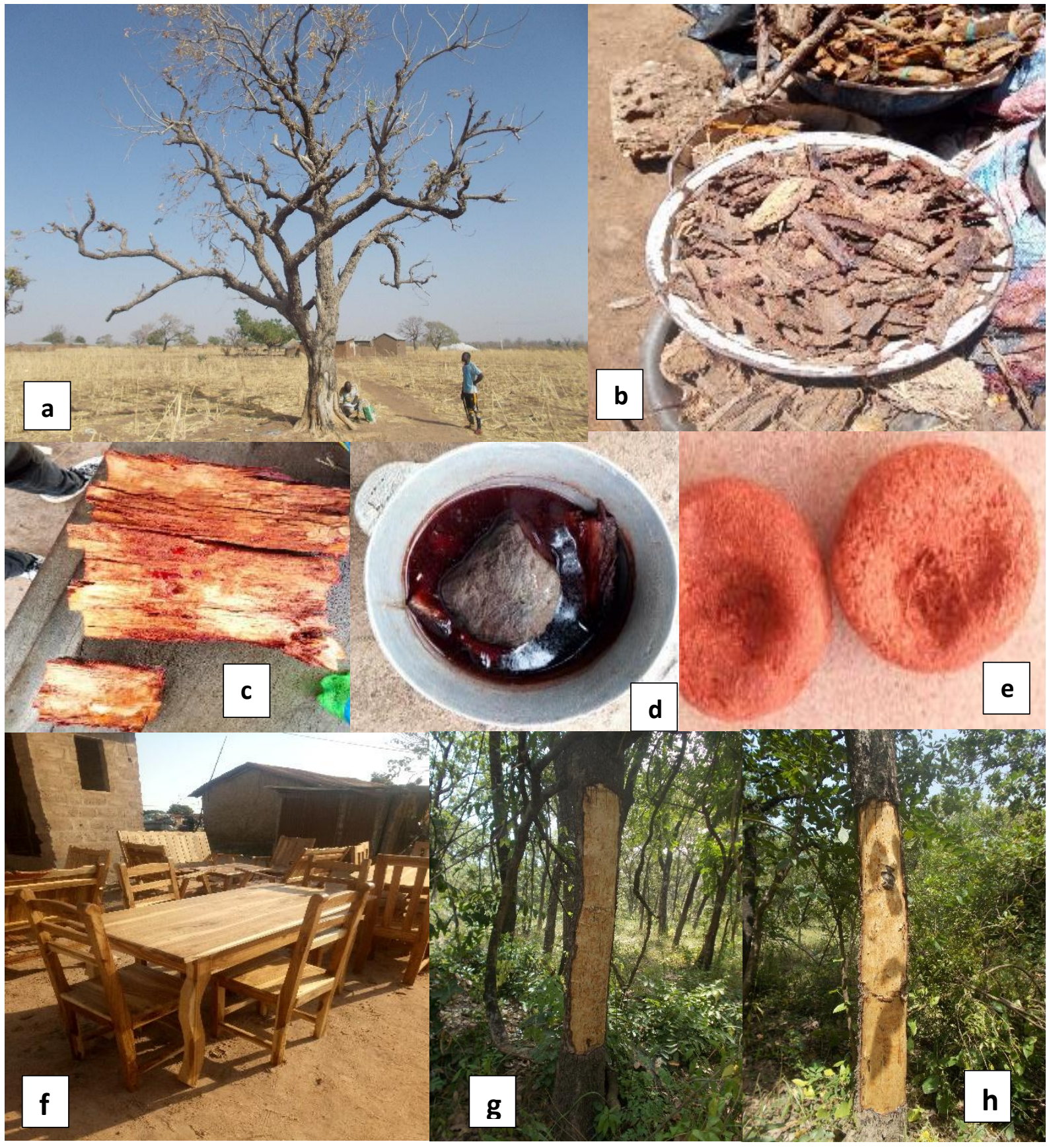

Figure 6. Some local uses of Pterocarpus erinaceus in Benin (a) Tree pruned frequently, (b, c) barks in herbalists' market, (d) decoction of the barks, (e) the "Tamaré" made with the heartwood is used as incense by the sociolinguistic groups Peulh and Bariba for evil spirits, (f) movables made with the wood, and $(g, h)$ tree barked.

Benin mostly in traditional medicine. Sixty-four diseases, symptoms, and pathologies cured by using the organs of $P$. erinaceus were identified. All the organs of the species are used and valued for various purposes, making $P$. erinaceus an important multi-use species that appears as a source of livelihood for a significant part of the population in Benin. Consequently, the species is subjected to anthropogenic pressures which can cause the species disappearance from natural habitats and even from farms and fallows. The various use forms of the organs of $P$. erinaceus revealed the need to define conservation strategies for the relict populations with a view to the sustainable use of the species. The scarcity of the species could impact on the income and health of people. To reverse the trends for livelihood activities and for improving the conservation status of the species, it is 
needed to combine both in-situ and ex-situ conservation forms in addition to the restriction provisions already taken against the extinction of the species. That should be possible with a participatory approach involving the sociolinguistic groups to design conservation schemes. Future investigations shall include the value chain studies on several products that could send signals to farmers to conserve the species. With regard to the medicinal importance of $P$. erinaceus, a panel study to diagnose the uses/demand of the species before and through the COVID-19 pandemic could reveal more the medicinal potential of the species.

\section{CONFLICT OF INTERESTS}

The authors have not declared any conflict of interests.

\section{ACKNOWLEDGEMENTS}

This work was partly supported by "Sud Expert Plantes Développement Durable (SEP2D)" program and its donors through the research project $N^{\circ}$ AAP-1_45. The authors are grateful to the respondents for freely sharing of their valuable knowledge on the species. The authors also appreciate the students (BSc.), S.C.B. Tokponwé, A.F. Sopodou, and C.M.M. Donhouédé for their assistance with data collection in the field.

\section{REFERENCES}

Adjonou K, Ali N, Kokutse AD, Kokou K (2010). Etude de la dynamique des peuplements naturels de Pterocarpus erinaceus Poir. (Fabaceae) surexploités au Togo. Bois et Forêts des Tropiques 306(1):45-55.

Agbani OP, Kafoutchoni MK, Salako VS, Gbedomon, CR, Kégbé MA, Hahn Karen H, Sinsin B (2018). Traditional ecological knowledgebased assessment of threatened woody species and their potential substitutes in the Atakora mountain chain, a threatened hotspot of biodiversity in Northwestern Benin, West Africa. Journal of Ethnobiology and Ethnomedicine 14(2):19.

Agbo RI, Vihotogbé R, Missihoun AB, Dagba RA, Assogbadjo AE, Agbangla C (2020). Indigenous knowledge of Detarium microcarpum Guill. \& Perr. (Caesalpiniaceae) and implication for conservation in Benin (West Africa). Environment, Development and Sustainability 22:6261-6285.

Alboukadel K, Mundt F (2020). Extract and Visualize the Results of Multivariate Data Analyses. R package version 1.0.7., 84. Available at: http://www.sthda.com/english/rpkgs/factoextra

Assogbadjo AE (2006). Importance socio-économique et étude de la variabilité écologique, morphologique, génétique et biochimique du baobab (Adansonia digitata L.) au Bénin. Thèse de doctorat. Faculty of Bioscience Engineering, Ghent University, Belgium. pp. 213.

Assogbadjo AE, Glèlè Kakaï R, Chadaré FJ, Thomson L, Kyndt T, Sinsin B, Van Damme P (2008). Folk classification, perception, and preferences of baobab products in West Africa: consequences for species conservation and improvement. Economic Botany 62(1):7484.

Barstow M (2018). Pterocarpus erinaceus. The IUCN Red List of Threatened Species e.T62027797A62027800.https://doi.org/10.2305/IUCN.UK.20182.RLTS.T62027797A62027800.en
Core Team R (2019). R: A language and environment for statistical computing. R Foundation for Statistical Computing, Vienna, Austria. Available at: https://www.R-project.org/

Dagnelie P (1998). Statistique théorique et appliquée. Tome 2, Inférence statistique à une et à deux dimensions. De Boeck (Edi.) $\mathrm{P}$ 659

Dassou GH, Adomou AC, Yédomonhan H, Ogni AC, Tossou GM, Dougnon JT, Akoègninou A (2015). Flore médicinale utilisée dans le traitement des maladies et symptômes animaux au Bénin. Journal of Animal and Plant Sciences 26(1):4036-4057.

Dovie DB, Witkowski E, Shackleton CM (2008). Knowledge of plant resource use based on location, gender and generation. Applied Geography 28(4):311-322.

Dumenu WK (2019). Assessing the impact of felling/export ban and CITES designation on exploitation of African rosewood (Pterocarpus erinaceus). Biological Conservation 236:124-133.

EIA (2017). The Rosewood Racket: China's Billion Dollar Illegal Timber Trade and the Devastation of Nigeria's Forests. (Washington DC).

Gbohaïda V, Mèdoatinsa SE, Nonviho G, Bogninou-Agbidinoukoun GSR., Agbangnan DCP, Sohounhloué CKD (2015). Etude chimique et évaluation de l'Influence de la granulométrie sur la cinétique d'extraction des polyphénols naturels de Pterocarpus erinaceus acclimaté au Bénin. International Journal of Innovation and Applied Studies 12(2):325-333.

Graves S, Piepho H-P, Selzer L, Dorai-Raj S (2019). Multcomp-View: Visualizations of Paired Comparisons. $\mathrm{R}$ package version 0.1-8. Available at: https://CRAN.R-project.org/package=multcompView

Houehanou TD, Assogbadjo AE, Kakaï Glèlè R, Houinato M, Sinsin B (2011). Valuation of local preferred uses and traditional ecological knowledge in relation to three multipurpose tree species in Benin (West Africa). Forest Policy and Economics 13(7):554-562.

Institut National de la Statistique et de l'Analyse Economique (INSAE) (2013). Résultats définitifs du RGPH4 : que retenir des effectifs de population en 2013. Institut National de la Statistique et de l'Analyse Economique, Cotonou, Bénin P 33. Available at: https://www.insaebj.org.

IUCN Red List Committee (2013). The IUCN Red List of Threatened Species Strategic Plan 2013 - 2020. Prepared by the IUCN Red List Committee. 392.

Johnson BN, Quashie MLA, Chaix G, Camus-kulandaivelu L, Adjonou K, Segla KN, Kokutse AD, Ouinsavi C, Bationo BA, Rabiou H, Kokou $\mathrm{K}$, Vignes $\mathrm{H}(2020)$. Isolation and characterization of microsatellite markers for the threatened African endemic tree species Pterocarpus erinaceus Poir. Ecology and Evolution 00:9.

Le S, Josse J, Husson F (2008). FactoMineR: An R Package for Multivariate Analysis. Journal of Statistical Software 25(1):1-18.

Levy PS, Lemeshow S (2008). Sampling of Populations: Methods and Applications. 4th Edition, John Wiley \& Sons, Hoboken. pp. 616.

Nantoumé H, Cissé S, Sow SP, Sidibé S, Kouriba A, Olivier A, Bonnville J, Cinq-Mars D (2018). Impact de rations comportant des fourrages de Pterocarpus lucens, Pterocarpus erinaceus et Ficus gnaphalocarpa sur l'embouche ovine au Mali. Tropicultura 36:673683.

Ouachinou JM-AS, Dassou GH, Azihou FA, Adomou CA, Yédomonhan $H$ (2018). Breeders' knowledge on cattle fodder species preference in rangelands of Benin. Journal of Ethnobiology and Ethnomedicine 14(66).

Ouachinou JM-AS, Dassou GH, Idohou R, Adomou AC, Yédomonhan H (2019). National inventory and usage of plant-based medicine to treat gastrointestinal disorders with cattle in Benin (West Africa). Sud African Journal of Botany 122:432-446.

Ouédraogo N, Lompo M, Sawadogo RW, Tibiri A, Hay AE, Koudou J, Dijoux MG, Guissou IP (2012). Etude des activités anti-inflammatoire, analgésique et antipyrétique des décoctés aqueux des feuilles et des racines de Pterocarpus erinaceus Poir. (Fabaceae). Phythérapie.

Ouinsavi C, Sokpon N (2008). Traditional agroforestry systems as tools for Milicia excelsa Welw. C.C. Berg genetic resources conservation in Benin. Agroforestry Système 74(1):17-26.

Ouinsavi C, Sokpon N, Khasa DP (2009). Genetic diversity and population structure of a threatened african tree species, Milicia excelsa, using nuclear microsatellites DNA markers. International Journal of Forestry Research P 8. 
Ouinsavi C, Sourou B, Houètchégnon T, Wédjangnon A, Dossa B, Akin Y, Dossou J, Houndjo, M-R (2019). Effect of cuttings diameter and indol acetic acid on rooting of Pterocarpus erinaceus Poir. stem cuttings. International Journal of Agroforestry and Silviculture 7(10):110.

Pohlert T (2014). The Pairwise Multiple Comparison of Mean Ranks Package (PMCMR). R package. Available at: https://www./CRAN.Rproject.org/package=PMCMR

Rabiou H, Bationo AB, Adjonou K, Kokutse DA, Mahamane A, Kokou K (2017a). Perception paysanne et importance socioculturelle et ethnobotanique de Pterocarpus erinaceus au Burkina Faso et au Niger. Afrique Science 13(5):43-60.

Rabiou H, Bationo BA, Laoual A, Segla KN, Adjonou K, Kokutse AD, Mahamane A, Kokou K (2017b). Vegetative propagation by aerial layering of Pterocarpus erinaceus: in the sudanian zone. International Journal of Recent Advances in Multidisciplinary Research 4(10):2902-2908.

Salako KV, Moreira F, Gbedomon RC, Tovissodé F, Assogbadjo AE, Glèlè Kakaï RL (2018). Traditional knowledge and cultural importance of Borassus aethiopum Mart. in Benin: interacting effects of socio-demographic attributes and multi-scale abundance. Journal of Ethnobiology and Ethnomedicine 14(36):14-36.

Sègla KN, Adjonou K, Radji AR, Kokutse AD, Kokou K, Rabiou $H$, Kamana P, Bationo B A., Mahamane A (2015a). Importance socioéconomique de Pterocarpus erinaceus Poir. au Togo. European Scientific Journal 11(23):199-217.

Sègla KN, Kokutse AD, Adjonou K, Langbour P, Chaix G, Guibal D, Kokou K, (2015b). Caractéristiques biophysiques du bois de Pterocarpus erinaceus (Poir.) en zones guinéenne et soudanienne au Togo. Bois et Forêts des Tropiques 324(2):51-64.
Sègla KN, Rabiou H, Adjonou K, Guibal D, Bationo AB, Mahamane A, Kokou K, Langbour P, Kokutse AD, Chaix G (2017). Useful near infrared spectroscopy model calibrations on solid wood samples of Pterocarpus erinaceus (Poir.) for physical, mechanical and colour properties. Journal of Near Infrared Spectroscopy 15(4):256-266.

Tardío J, Pardo-de-Santayana M (2008). Cultural Importance Indices: A Comparative Analysis Based on the Useful Wild Plants of Southern Cantabria (Northern Spain). Economic Botany 62(1):24-39.

Tittikpina NK, Agban A, Gbogbo KA, Hoekou YP, Pereki H, Batawila K, Akpagana K (2013). Evaluation des propriétés antimicrobiennes de Pterocarpus erinaceus Poir (Faboïdeae) et Daniellia oliveri (Rolfe) Hutch. et Dalz (Caesalpinoïdeae), utilisées en médecine traditionnelle au Togo. International Journal of Biological Chemical Sciences 7(4):1586-1594.

Wanjohi BK, Njenga, EW, Sudoi V, Kipkore WK, Moore HL, Davies MIJ (2020). Ecological Knowledge of indigenous plants among the Marakwet Community (Embobut Basin), Elgeyo Marakwet County (Kenya). Ethnobotany Research and Applications 20(1):1-16. 